\title{
Production of Protein Isolates from Chilean Granado Bean (Phaseolus vulgaris L.)
}

\author{
Priyanka Kumar ${ }^{1}$, Bih King Chen ${ }^{2}$, Sayeh Sinichi², Veronica Dueik ${ }^{3}$, David Carré ${ }^{3}$, and \\ Levente Diosady ${ }^{2}$
}

${ }^{1}$ Loughborough University

${ }^{2}$ University of Toronto

${ }^{3}$ Comercial e Industrial Solutec Ltda

May 18, 2020

\begin{abstract}
The Chilean granado bean (Phaseolus vulgaris L.) contains nutritionally valuable proteins, and there was indication that the proteins can help in the prevention of diabetes. To further explore tis potential purified samples of the bean proteins is required. A membrane-based process was developed for the isolation of proteins from granado beans, adapted from methods reported earlier for mustard protein processing. The optimised process consists of alkaline protein extraction from granado bean flour at $\mathrm{pH} 10$, ultrafiltration at concentration factor 4 and diafiltration with diavolume 4 followed by isoelectric protein precipitation at $\mathrm{pH}$ 4. The process starting with granado beans containing $28 \%$ protein, recovered $60.1 \%$ of the protein as precipitated protein isolate (PPI) and $7.2 \%$ as acid soluble protein isolates (SPI). The losses in the process system were approximately $26 \%$ of mass and $18.8 \%$ of nitrogen due to removal of non-protein nitrogen and small molecular weight components, likely carbohydrates. The protein contents of the PPI and SPI were $\sim 92 \%$ and $62 \%$ on a moisture-free basis; the protein content of the SPI produced is considerably lower than typical isolates. This may be due to the co-recovery of high molecular weight carbohydrates. The water absorption capacity and nitrogen solubility index, of the PPI and SPI were measured and compared to other oilseed isolates. The PPI showed high water absorption $(<400 \%)$. SPI dissolved completely - a nitrogen solubility index of $100 \%$, while PPI had low nitrogen solubility near its isoelectric point. Both isolates had traits desirable for easy incorporation into food products.
\end{abstract}

\section{Introduction}

The common bean (Phaseolus vulgaris), a legume of the bean and pea family, is a key source of nutrients for more than 300 million people in East Africa and Latin America (Petry et al., 2015). The diets of the impoverished populations in Africa and Latin America are often poor in proteins, which are typically derived from legumes. In countries such as Chile and Mexico, beans are the primary source of protein in human diets; in particular, the common bean makes up half the grain legumes consumed worldwide (Broughton et al., 2003).

The granado bean is a common bean that is only produced in Chile, and it is typically consumed locally without further processing. In Chile, approximately $64 \%$ of the population are overweight or obese (GHI, 2018), and at least 9\% have type II diabetes (International Diabetes Federation, 2017). A major contributor to this epidemic is the consumption of products that are high in starch, sugar and fats. As a result, there is a desire to reduce these undesirable components and to replace them with healthier ingredients in food products. The nutritive value and high protein content of the granado bean means that it can be processed and used for the formulation of these healthier foods (Bascur et al., 2014). Therefore, the principal processing 
methods investigated and developed in this research, specifically for the production of granado bean protein, has the potential to provide significant health benefits to the Chilean population.

Oilseeds are seeds and legumes are grown for their high protein content (Potter and Hotchkiss, 1995). Many processes have been developed for the extraction of proteins and oil from oilseeds, such as soy, canola and mustard (Sinichi et al, 2014, 2015 and 2019). Membrane based procedures for protein isolate production commonly involve oil extraction, solubilisation of protein, protein precipitation, purification and drying. The resulting products are protein concentrates and/or isolates. Protein concentrates contain at least $65 \%$ protein, whereas protein isolates are highly refined, containing over $90 \%$ protein on a moisture-free basis (Endres, 2001).

Tzeng et al. (1990) developed the first membrane-based process for producing canola protein isolates from defatted, oil-free meal. It consisted of five key steps: alkaline extraction, ultrafiltration followed by diafiltration, isoelectric precipitation and drying. This formed the basis of later membrane-based methods for other oilseeds, including Marnoch and Diosady's (2006) process for oriental mustard seed. The preparation of the initial oil-free meal, produced from the extraction of oil from oilseeds, is not necessary for legumes, due to their low oil content. Therefore, this preliminary step can be omitted and flour produced from legumes can be used as the starting material.

The utilisation of protein isolates from legumes and oilseeds is limited by the presence of undesirable and anti-nutritional components. Glucosinolates, phenolics and phytates are components that hinder the bioavailability of amino acids and minerals (Marnoch and Diosady, 2006). Therefore, the concentration of these compounds must be reduced before protein isolates can be used for human consumption. In particular, phenolic compounds are difficult to remove as some bind to the proteins in aqueous media to form phenolic-protein complexes. In addition, these complexes are also responsible for the astringent flavour and dark colour of protein isolate products (Marnoch and Diosady, 2006). Therefore, methods have been developed for the preparation of protein isolates essentially free of phenolics. One method developed by Diosady et al. (2011) liberates oilseed protein isolates from phenolics by introducing a heating step and membrane filtration to the extraction process.

For a protein isolate to be useful as a food ingredient, it must have good food functionality, a well-balanced amino acid composition, and acceptable organoleptic properties. Protein isolates from legumes generally have a high protein content and satisfactory amino acid composition; but the organoleptic properties of the granado bean protein isolates are yet to be reported. The importance of protein isolates when used in food systems relies not only on their nutritional value, but also on their technological functionality. Functional properties such as water absorption and nitrogen solubility enhance food sensory and organoleptic characteristics.

The objective of this work was to develop an effective process for the production of protein isolates from granado beans, through the adaptation of the methods developed for oilseeds, in particular that of the method developed by Marnoch and Diosady (2006) for oriental mustard seeds. The protein content of the granado bean and the protein isolates produced were evaluated, in order to quantify the protein recovery. To determine the quality of isolates the functional properties of the protein isolates, were determined in order to evaluate the potential usefulness of the isolates in food systems. The protein products will be used to explore the potential of some or all of the proteins in the isolates for the prevention of diabetes.

\section{Materials and Methods}

Samples were prepared from whole granado beans received from Commercial e Industrial Solutec Ltda. (Santiago, Chile), by grinding to a flour and passing through a \#45 USA standard testing sieve with 0.355 $\mathrm{mm}$ openings. All tests were done from a single pooled sample.

\section{Extraction of Proteins}

The extractability of the proteins from the granado bean flour was determined at several $\mathrm{pH}$ values between $\mathrm{pH} 2$ and $\mathrm{pH} 11$. Ten grams of the sample was dispersed thoroughly in a beaker with $180 \mathrm{~mL}$ of distilled 
water, then well stirred with a magnetic stirrer as dilute $(1 \mathrm{M}$ or $2 \mathrm{M}) \mathrm{H}_{3} \mathrm{PO}_{4}$ or $50 \% \mathrm{NaOH}$ solution was added to bring the suspension to a preselected $\mathrm{pH}$. During the extraction, the $\mathrm{pH}$ was measured using a $\mathrm{pH}$ probe, and kept constant by the slow addition of the acid or alkali for $30 \mathrm{~min}$ at room temperature. The protein solution was then separated from the undissolved meal by centrifugation at 9000xg for $20 \mathrm{~min}$. The

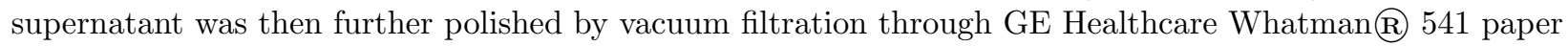
to remove any fine particles. The protein content of the solution was analysed using AOCS method Ba 4d-90, known as the Kjeldahl nitrogen method, using a Büchi 425 digestion unit and a K-350 distillation unit. The extractability was determined as the weight of protein in the extract solution compared to that of the $10 \mathrm{~g}$ starting sample.

Extractability $(\%)=\frac{\text { protein }(\mathrm{g}) \text { in extract }}{\text { protein in } 10 \mathrm{~g} \text { of starting flour }} \times 100$

The extractability profile was plotted in the range from $\mathrm{pH} 2$ to $\mathrm{pH} 11$. The results are presented in Figure 1.

\section{Precipitation of Dissolved Proteins}

In order to determine the optimal precipitation $\mathrm{pH}, 400 \mathrm{~g}$ of protein extract solution was prepared at $\mathrm{pH} 10$, using the same methods as for determining the extractability of the proteins. The $\mathrm{pH}$ was then adjusted to the preselected $\mathrm{pH}$ values, from $\mathrm{pH} 3.5$ to $\mathrm{pH} 5.5$ by the addition of $6 \mathrm{M} \mathrm{H}_{3} \mathrm{PO}_{4}$. This was maintained constant for $30 \mathrm{~min}$ at room temperature for precipitation. The precipitate was then centrifuged at $9000 \mathrm{xg}$ for $20 \mathrm{~min}$, then a wet cake and clarified solution were collected. The cake was dried overnight at $105^{\circ} \mathrm{C}$. The protein content of both the dried cake and supernatant was measured using the Kjeldahl nitrogen method (AOCS method $\mathrm{Ba} 4 \mathrm{~d}-90$ ). The yield from the extracted protein is reported as the weight ratio of protein in the precipitate to that in the starting $400 \mathrm{~g}$ of the $\mathrm{pH} 10$ extract.

$$
\text { Protein }(\%)=\frac{\text { protein }(\mathrm{g}) \text { in precipitate }}{\text { protein in starting extract }} \times 100
$$

\section{Processing for Protein Recovery}

The membrane-based process developed by Marnoch and Diosady (2006) was used as the basis for the development of the procedure for producing protein isolates from granado bean flour. For the extraction and precipitation stages, the previously determined optimal $\mathrm{pH}$ levels were used. For the filtration stage, the extract solution was subject to membrane processing at $345 \mathrm{kPa}$, first by ultrafiltration using a Millipore Pelicon@ 2 filtration system and a $10 \mathrm{kDa}$ membrane at a chosen concentration factor $(\mathrm{CF})$. Then, the extract was further purified by continuous diafiltration. For diafiltration, the ultrafiltration unit was operated at a chosen constant volume (diavolume, DV) by the addition of buffered water to the feed tank, at the same rate as the permeate flowrate, so that a constant volume of retentate was maintained throughout (Cheryan, 1998).

Two types of protein products were isolated: precipitated protein isolates (PPI) and acid soluble protein isolates (SPI). The protein contents of both products and the flour residue were then determined using the Kjeldahl method (AOCS Ba 4d-90).

\section{Nitrogen Solubility Index and Water Absorption Capacity}

Basic functional properties of both granado bean protein isolates (SPI and PPI) were investigated.

The water absorption capacity was determined following the method developed by Naczk et al. (1985). Two grams of the SPI or PPI sample was dispersed in $16 \mathrm{ml}$ of distilled water, by repeatedly mixing for 10 sec every $30 \mathrm{sec}$, eight times. This solution was then centrifuged at $2000 \mathrm{xg}$ for $15 \mathrm{~min}$ and decanted immediately afterwards. The precipitate was then drained of liquid and weighed. The water absorption capacity is reported 
as the percentage increase of the initial sample weight.

$$
\mathrm{WAC}=\left(\mathrm{W}_{\mathrm{f}} / \mathrm{W}_{\mathrm{i}}\right) 100
$$

where WAC is the Water Absorption Capacity (\%), $W_{f}$ is the final weight of the sample after water decanting and $W_{i}$ is the initial weight of the sample.

The nitrogen solubility index was determined based on AOCS method Ba 11-65. Five grams of the SPI or PPI sample was dispersed in $200 \mathrm{~mL}$ of distilled water, then stirred in a water-bath stirrer at $30^{\circ} \mathrm{C}$ for 120 min. The solution was made up to $250 \mathrm{~mL}$ in a volumetric flask by the addition of distilled water, before centrifugation at $2000 \mathrm{xg}$ for $10 \mathrm{~min}$. The supernatant was decanted and filtered through a plug of glass fibre. SPI centrifugation was carried out at 9000xg for 20 minutes, as a clear separation of solids from the liquid was not achieved at $2000 \mathrm{xg}$. Increasing the centrifugation rate made decanting the liquid easier. To produce

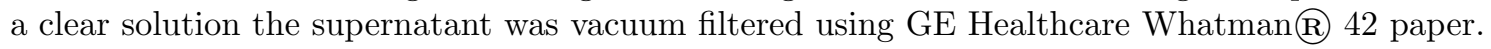

The Nitrogen Solubility Index (NSI) is a function of the Water-Soluble Nitrogen (WSN) and the measured nitrogen content $(\mathrm{N})$ of the initial sample:

$$
\mathrm{NSI}=(\mathrm{WSN} / \mathrm{N}) 100
$$

The water-soluble nitrogen is the nitrogen dissolved in the collected filtrate.

Data Analysis

All samples of granado bean flour received from Chile were pooled. All protein analyses were done in triplicate, and the relative standard deviation of all analyses were less than $2 \%$.

The isolation process was very lengthy and labour intensive. As indicated in the results, the complete process was repeated three times, and the averages \pm standard error were reported.

\section{Results and Discussion}

\section{Starting Material}

It should be noted that the Kjeldahl nitrogen method estimates the crude protein content of the sample, as the nitrogen content times 6.25 ( Nx6.25), according to the standard practice of the food industry. It therefore includes the non-protein nitrogen compounds and typically overestimates the protein content. All measurements of protein refer to this crude protein measurement, as the analytical method used was consistent throughout. The crude protein content of the granado bean flour was $27.9 \%$; flour prepared from dehulled granado beans it was $29.6 \%$, significantly higher than the literature value of $22-23 \%$, and that of other legumes used as protein sources, but lower than the protein content of soybeans (Joshi et al.). The composition of the granado bean flour is shown in Table 1.

\section{Protein Extractability}

The plot of protein extractability (Figure 1) has a minimum near $\mathrm{pH} 4$, where only $19 \%$ of the protein was extractable. There is a sharp increase in protein extractability from $\mathrm{pH} 3$ to $\mathrm{pH} 2$, and from $\mathrm{pH} 6$ to $\mathrm{pH} 7$. In the alkali range the extractability of the proteins gradually increases, from $80 \%$ at $\mathrm{pH} 7$ to $89 \%$ at $\mathrm{pH}$ 11. While higher solubility may be achieved above $\mathrm{pH} 11$, much more $\mathrm{NaOH}$ is required to achieve these high $\mathrm{pH}$ levels, which is impractical on a larger scale. In addition, exposure of proteins to high $\mathrm{pH}$ has been reported to increase the possibility of lysinoalanine formation, which could render the isolate toxic (Freidman et al., 1979 and Hou et al., 2017). In the acid range, $\mathrm{pH}$ values lower than $\mathrm{pH} 2$ were not explored, as a significant amount of $\mathrm{H}_{3} \mathrm{PO}_{4}$ was required to bring the $\mathrm{pH}$ of the solution to $\mathrm{pH} 2$ from $\mathrm{pH}$ 3. Therefore, for the protein isolation process, $\mathrm{pH} 10$ was selected for the extraction stage for its high extractability $(87.5 \%)$ and practicality. 


\section{Protein Precipitation}

As the minimum solubility (isoelectric point) was determined to be near $\mathrm{pH} 4$, the $\mathrm{pH}$ range tested for protein precipitation was $\mathrm{pH} 3.5$ to $\mathrm{pH} 5.5$. Of the proteins dissolved in the starting solution, $70-75 \%$ was recovered as precipitated protein within this $\mathrm{pH}$ range. The protein content in each of these precipitates was 83-90\% on a dry basis. The percentage of proteins that were precipitated was calculated from the amount of protein measured in the precipitate, and the percentage of proteins that remained dissolved was calculated from the amount of protein measured from the supernatant. As expected, the maximum protein precipitation $(72.8 \%)$ was observed at the point of minimum solubility, $\mathrm{pH} 4$ (Figure 2).

\section{Protein Isolation Process}

The process flow diagram for the finalized procedure for the isolation of granado bean protein isolates is presented in Fig. 3. It consisted of well mixing water and granado flour at a water-to-flour weight ratio (R) of 12 . The $\mathrm{pH}$ of the mixture was then raised to the optimal extraction $\mathrm{pH}$ of 10 by the slow addition of $50 \% \mathrm{NaOH}$ solution. The resulting suspension was then maintained at $\mathrm{pH} 10$ for $45 \mathrm{~min}$.

After the protein extraction, centrifugation separated the undissolved material from the extract solution. The resulting wet cake was washed twice $(\mathrm{R}=6)$ with water. After separation by centrifugation, the solid residue was neutralized and freeze dried, and the wash solutions were combined with the extract solution. To dissociate any ionically bound phenolic colour and flavour compounds from the proteins $3 \mathrm{~g} / \mathrm{L} \mathrm{NaCl}$ was added and the solution was then heated to $55 \operatorname{deg} C$ and maintained for 30 minutes. It was then concentrated and purified by membrane processing using a $10 \mathrm{kDa}$ molecular weight cut-off polyethersulphone membrane. Ultrafiltration at a concentration factor of 5.5 was followed by diafiltration at a diavolume of 3.5 using a freshly made $0.05 \mathrm{M} \mathrm{NaCl}$ solution adjusted to $\mathrm{pH} 10$ with $\mathrm{NaOH}$.

Next, the diafiltration retentate was acidified to $\mathrm{pH} 4$, the optimal $\mathrm{pH}$ for precipitation, by the addition of $6 \mathrm{M} \mathrm{H}_{3} \mathrm{PO}_{4}$,precipitating the bulk of the proteins, which were then recovered by centrifugation.

The solid cake recovered by centrifugation was freeze-dried to produce isoelectric precipitated protein isolates (PPI). The clear supernatant, which contained the soluble proteins, was ultra- and diafiltered to reduce its volume and to increase its purity. The retentate was then freeze-dried to produce acid soluble protein isolates (SPI).

\section{Protein Isolates}

The terms "protein isolate" and "protein concentrate" have been defined two different ways. The standard terminology is based on composition and defines isolates as products with $<90 \%$ protein and concentrates as $60-75 \%$ protein. The terms can be defined also by the process: isolates are obtained by dissolving, purifying and reprecipitating protein, while concentrates are obtained by dissolving undesirable components, maintaining the proteins undissolved. As the paper describes a process we used the process-based definitions.

Following the process outlined in Fig. 3, protein isolates were produced from batches of $80 \mathrm{~g}$ of ground granado bean flour. The initial extract produced was very cloudy, meaning that it would require a long filtration duration. However, the combined extract, containing the extract and the two water washes was less cloudy and permitted a reasonable filtration rate. Table 2 shows the mass and protein distribution in PPI, SPI and meal residue from the complete process. $60 \%$ of the protein was recovered as PPI, $7.2 \%$ as SPI and $13.9 \%$ remained unextracted in the meal residue. Some $26 \%$ of mass containing $18.8 \%$ of the original nitrogen representing non-protein nitrogen and small molecular weight carbohydrates were lost in the permeates.

The protein isolation process was repeated three times. To speed up the process, and provide some products for further testing the two washing steps were skipped in these runs. The mass yield decreased to $13.5 \%$ PPI and 3.1\% SPI (as is basis). The PPI contained $84.0+/-2.9$ wt. \% crude protein (+/- Standard Error), and the SPI contained $53.0+/-3.1$ wt. $\%$ crude protein. 
The SPI contained only some $60 \%$ protein, which is significantly lower than the typical SPI protein concentration reported for mustard and canola by similar processes (Marnoch and Diosady, 2006). Unlike mustard, the granado beans contain a significant fraction of soluble high molecular weight starch which would be retained by the membrane, and be recovered from the retentate, diluting the acid soluble protein fraction.

Both isolated products have an attractive, light colour; the PPI was pale creamy in colour, the SPI was nearly white (see Fig. 4). Both isolates had a smooth mouthfeel and were bland in taste. The precipitated isolate (PPI) resulted in a very slight, lingering bitter aftertaste, which should be readily masked in a food product.

\section{Water Absorption Capacity and Nitrogen Solubility}

The functional property tests were performed in triplicate at the intrinsic $\mathrm{pH}$ of the granado bean protein products.

These functional properties of other similarly prepared protein isolates are listed in Table 3, including the testing conditions for reference. As expected, since measurement was done at the isoelectric point of the protein, the nitrogen solubility index (NSI) of the granado bean PPI was very low (1.7\%). similarly to that of yellow mustard PPI. A low nitrogen solubility index reflects the low solubility of the protein isolate at the measurement $\mathrm{pH}$, limiting its use in some food

The water absorption capacity of the granado bean PPI was very high, similarly to soybean isolates. On the other hand, the granado bean SPI has the highest NSI value (100\%), similar to that of Chinese rapeseed SPI and greater than commercial soybean isolate. This is desirable, as the capacity to retain moisture influences the texture and mouth-feel of foodstuffs (Kinsella and Melachouris, 1976). As the SPI dissolved in the added water its water absorption capacity could not be determined.

\section{Conclusions}

A process for the production of protein isolates from Chilean granado bean flour by aqueous extraction, complex dissociation, membrane processing, followed by isoelectric precipitation was developed. The PPI contained $<90.0 \%$ crude protein on a dry basis. The protein content of the SPI was relatively low due, most likely, to entrained high molecular weight soluble carbohydrates (starches) .

The protein extractability of the bean was high, ranging from $81 \%$ to $89 \%$ at $\mathrm{pH} 8$ to $\mathrm{pH} 11$. The optimal $\mathrm{pH}$ for protein precipitation was identified as $\mathrm{pH}$. The process recovered $<80 \%$ of the protein as useful products: PPI, SPI and a meal residue.

The nitrogen solubility and the water holding capacity of the isolates produced from granado bean were also investigated. The nitrogen solubility index of the PPI was very low (1.7\%), and the SPI was the highest $(100 \%)$, suggesting complete solubilisation of the proteins. The water absorption capacity of the PPI was $<400 \%$, competitive with soy protein isolates. The SPI was extremely soluble in water, making it impossible to define its water absorption capacity. Other functional properties relating to the structure of the isolates were not yet determined. The results indicate that granado beans are a potential source of high quality food ingredients, providing other vegetable protein products that can complement soy proteins and other vegetable proteins now entering the food system. As there were early indications that granado beans may be effective in the prevention of diabetes, further research will focus on the evaluation of the isolates, and their fractionation.

\section{References}

AOCS, 1998. Official methods and recommended practices of the AOCS.American Oil Chemists' Society, Champaign.

Bascur, G., Pino, M.T. and Gonzalez, M., 2014. Desarrollo de Variedades chilenas de Poroto verde y Granado para congelado, con alto valor agroindustrial y culinario, para el Mercado Interno y de Exportacion, 
Utilizando Tecnicas Biotecnologicas Modernas. Instituto de investigaciones agropecuarias , Newsletter No. 24.

Broughton, W.J., Hernandez, G., Blair, M., Beebe, S., Gepts, P. and Vandeleyden, J., 2003. Bean (Phaseolus spp.) - model food legumes.Plant and Soil , 252, pp.55-128.

Cheryan, M., 1998. Ultrafiltration and Microfiltration Handbook. Technomic, Lancaster, PA.

Diosady, L.L., Xu, L. and Chen, B-K, 2011. Production of high-quality protein isolated from oil seeds, U.S. Patent 8,048,463.

Endres, J.G., 2001. Soy Protein Products Characteristics, Nutritional Aspects, and Utilization. American Oil Chemists' Society, Champaign IL, p.6.

Friedman, M., Levin, C.E. and Noma, A.T., 1984. Factors Governing Lysinoalanine Formation in Soy Proteins. Journal of Food Science, 49(5), pp.1282-1288.

GHI, 2018. Overweight and obesity rates in Latin America as of June 2018, by selected countries. Statista . Accessed June 6, 2019. Available from https://www.statista.com/statistics/883867/latin-americadistribution-rate-overweight-obesity/.

Hou, F., Ding, W., Qu, W., Oladejo, A.O., Xiong, F., Zang, W., He, R., and Ma, H., 2017. Alkali solution extraction of rice residue protein isolates: Influence of alkali concentration on protein functional, structural properties and lysinoalanine formation. Food Chemistry, 218, pp. 207-215.

International Diabetes Federation, 2017. IDF Diabetes Atlas, Eighth edition. Accessed June 6, 2019.

Available from https://www.diabete.qc.ca/en/understand-diabetes/resources/getdocumentutile/IDF-DA8e-EN-finalR3.pdf.

Johnson, L.A., White, P.J. and Galloway, R., 2008. Soybeans - Chemistry, Production, Processing, and Utilization, AOCS Press, Urbana IL, pp. 684-687.

Joshi, A.U., Liu, C. and Sathe, S.K., 2015. Functional properties of select seed flowers. LWT - Food Science and Technology , 60(1), pp.325-331.

Kinsella, J.E. and Melachouris, N., 1976. Functional properties of proteins in foods: A survey. $C R C$ Critical Reviews in Science and Nutrition , 7(3), pp.219-280.

Marnoch, R., and Diosady, L.L, 2006. Production of Mustard Protein Isolates from Oriental Mustard Seed (Brassica juncea L.). Journal of the American Oil Chemists' Society , 83, pp.65-69.

Naczk, M., Diosady, L.L. and Rubin, L.J., 1985. Functional properties of canola meals produced by a two-phase solvent-extraction system. Journal of Food Science, 50(6), pp.1685-1692.

Pedroche, J., Yust, M.M., Lqari, H., Giron-Calle, J., Alaiz, M.m Vioque, J., Millan, F., 2004. Brassica carinata protein isolates: chemical composition, protein characterization and improvement of functional properties by protein hydrolysis. Food Chemistry , 88(3), pp.337-346.

Petry, N., Boy, E., Wirth, J.P. and Hurrell, R.F., 2015. Review : The Potential of the Common Bean (Phaseolus vulgaris) as a Vehicle for Iron Biofortification. Nutrients , 7(2), pp.1144-1173.

Potter, N.N. and Hotchkiss, J.H., 1995. Cereal Grains, Legumes, and Oilseeds. In: Food Science. Food Science Text Series. Springer, Boston, pg.381.

Sinichi, S., Diosady L.L., 2014. Isopropyl alcohol extraction of dehulled yellow mustard flour. Journal of the American Oil Chemists' Society . 91(12), pp.2143-2153.

Sinichi, S., Diosady L.L., 2015. Isopropyl alcohol extraction of mustard oil. International News on Fats, Oils, and Related Materials . 26(3), pp.178-182. 
Sinichi S, Legorreta Sianez AV, Diosady L.L., 2019. Recovery of Phenolic Compounds from the By-product of Yellow Mustard Protein Isolation. Journal of Food Research International, 115, pp.460-466

Tabtabei, S., Hijar, B., Chen, B-K. and Diosady, L.L., 2016. Functional Properties of Protein Isolates Produced by Aqueous Extraction of De-hulled Yellow Mustard. Journal of the American Oil Chemists' Society, 94, pp.149-160.

Tzeng, Y.M., Diosady, L.L., and Rubin, L.J., 1990. Production of Canola Protein Materials by Alkaline Extraction, Precipitation, and Membrane Processing, Journal of Food Science, 55, pp.1147-1156.

Q-Q.Yang, R-Y. Gan, Y-Y. Ge, D. Zhang, H. Corke Polyphenols in Common Beans (Phaseolus vulgaris L.): Chemistry, Analysis, and Factors Affecting Composition - Comprehensive Reviews in Food Science and Food Safety, First published: 11 October 2018

https://doi.org/10.1111/1541-4337.12391

Table 1 Composition of granado bean flour as received

\begin{tabular}{ll}
\hline & Percentage $\% \mathrm{w} / \mathrm{w}$ \\
\hline Hull & 8.1 \\
Protein & 27.9 \\
Oil Moisture & 3.09 .2 \\
\hline
\end{tabular}

Table 2 Protein distribution

\begin{tabular}{lllll}
\hline & $\begin{array}{l}\text { Mass distribution } \\
(\%)\end{array}$ & $\begin{array}{l}\text { Protein Content } \\
\text { As is (\%) }\end{array}$ & $\begin{array}{l}\text { Protein Content } \\
\text { Moisture free (\%) }\end{array}$ & $\begin{array}{l}\text { Protein } \\
\text { Distribution (\%) }\end{array}$ \\
\hline Granado Flour & 100 & 27.9 & 30.7 & 100 \\
PPI & 19.1 & 87.7 & 92.3 & 60.1 \\
SPI & 3.4 & 59.1 & 62.2 & 7.2 \\
Meal Residue & 51.5 & 7.4 & 7.8 & 13.9 \\
Unrecovered & 26 & 20.1 calculated- & - & 18.8 \\
\hline
\end{tabular}

Table 3 Functional properties of different protein isolates, including granado bean precipitated and soluble protein isolates ( ${ }^{1}$ Tabtabei et al., 2016)

\begin{tabular}{lllll}
\hline & $\begin{array}{l}\text { Processing } \\
\text { conditions }\end{array}$ & $\begin{array}{l}\text { Processing } \\
\text { conditions }\end{array}$ & NSI (\%) & WAC (\%) \\
\hline Starting Material & Extraction & $\begin{array}{l}\text { Protein } \\
\text { Precipitation } \\
\text { pH } 5.5\end{array}$ & 1.4 & 131 \\
$\begin{array}{l}\text { Yellow Mustard } \\
\text { PPI }^{1}\end{array}$ & $\mathrm{pH} 11$ & $\mathrm{pH} 5.5$ & 39.5 & - \\
$\begin{array}{l}\text { Yellow Mustard } \\
\text { SPI }^{1}\end{array}$ & $\mathrm{pH} 11$ & $\mathrm{pH} 6.5$ & 2.8 & 219 \\
Chinese Rapeseed $^{1}$ & $\mathrm{pH} 12$ & $\mathrm{pH} 6.5$ & 95.3 & - \\
PPI $^{1}$ & $\mathrm{pH} 12$ & & &
\end{tabular}




\begin{tabular}{lllll}
\hline & $\begin{array}{l}\text { Processing } \\
\text { conditions }\end{array}$ & $\begin{array}{l}\text { Processing } \\
\text { conditions }\end{array}$ & & \\
\hline $\begin{array}{l}\text { Commercial } \\
\text { Soybean isolate } \\
\text { Supro 500E) }\end{array}$ & - & $\mathrm{pH} 4.2$ & 82.8 & 461 \\
$\begin{array}{l}\text { Granado bean } \\
\text { PPI }\end{array}$ & $\mathrm{pH} 10$ & $\mathrm{pH} 4$ & 1.7 & 406 \\
$\begin{array}{l}\text { Granado bean } \\
\text { SPI }\end{array}$ & $\mathrm{pH} 10$ & $\mathrm{pH} 4$ & 100 & - \\
\hline
\end{tabular}

Figure captions

Figure 1 Protein extractability of ground granado bean flour as a function of $\mathrm{pH}$

Figure 2 Precipitated and dissolved protein composition of the protein extract solution after precipitation, at varying $\mathrm{pH}$

Figure 3 Process flow schematic, showing the steps for producing final protein products from granado bean flour

Figure 4 Soluble Protein Isolates (SPI) (left), and Precipitated Protein Isolates (PPI) (right) produced from granado bean flour.

\section{Hosted file}

Cover_letter_revision_.docx available at https://authorea.com/users/323645/articles/452208production-of-protein-isolates-from-chilean-granado-bean-phaseolus-vulgaris-1

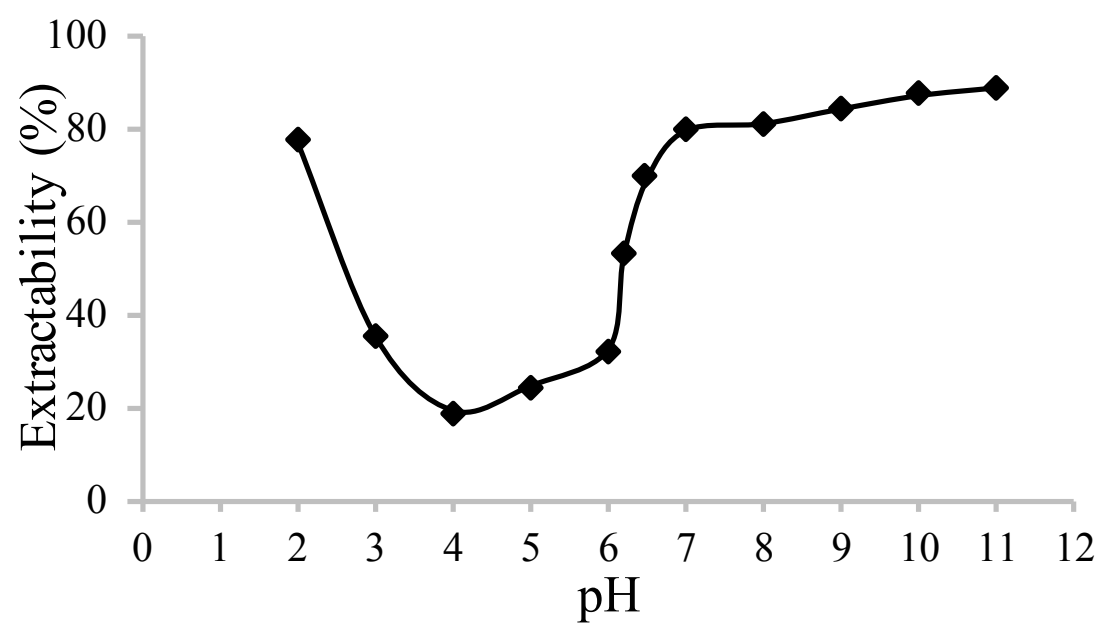




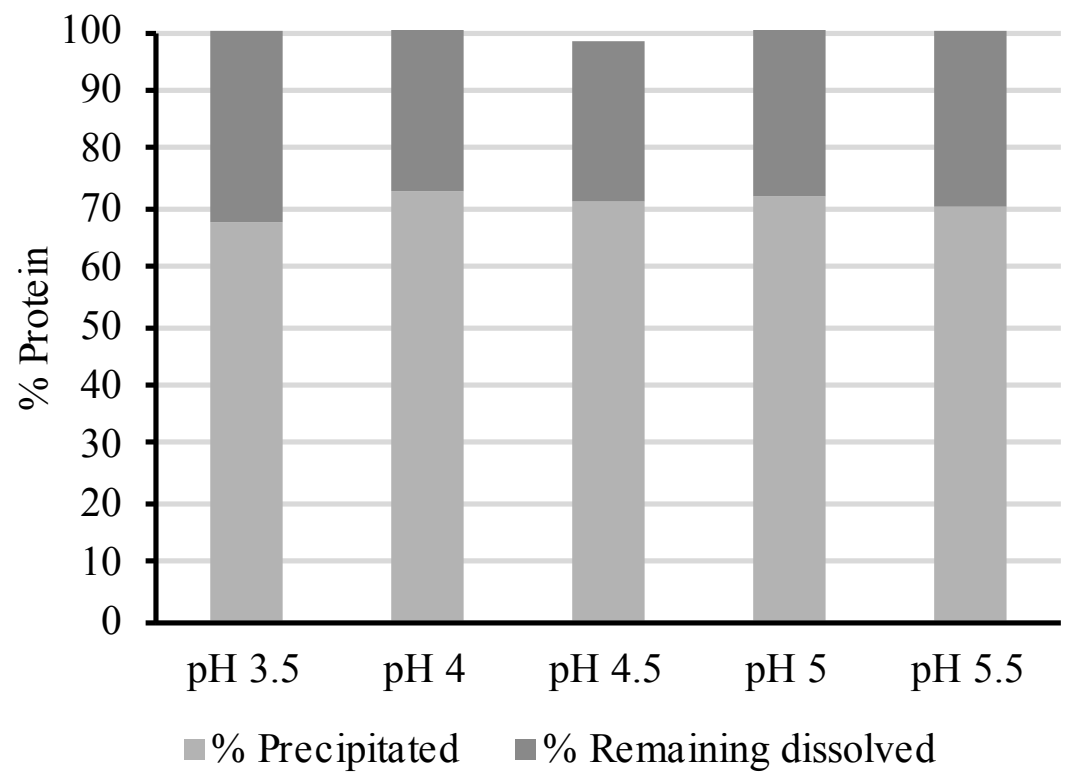




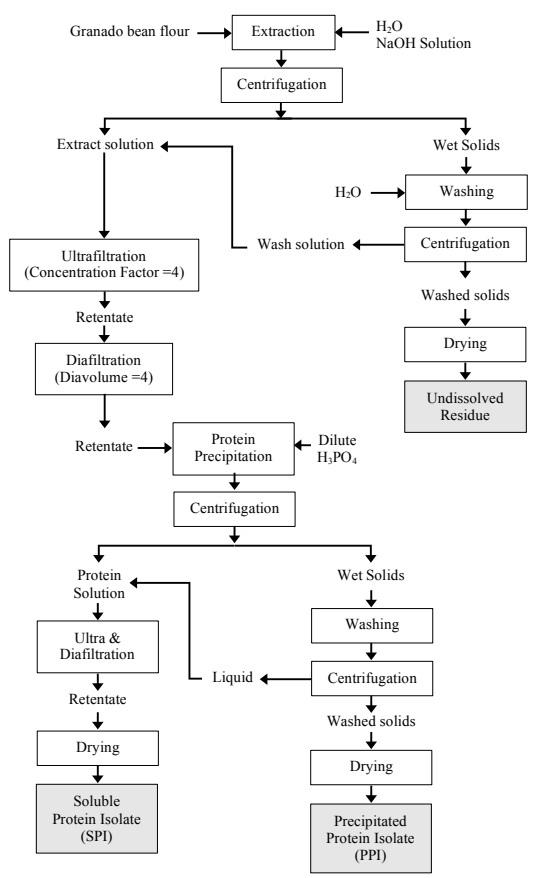



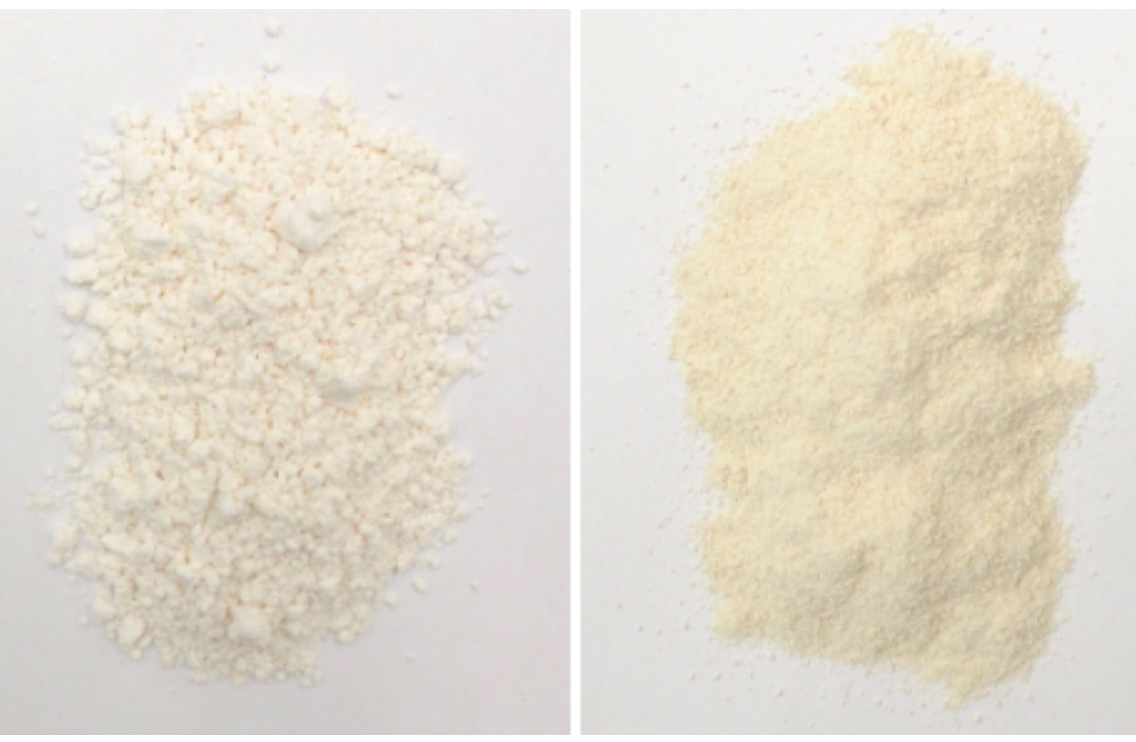